\title{
In-vitro Examination of The Potential Antibacterial Activity of Simvastatin
}

\author{
Hani M. Almukhtar ${ }^{1 *}$, Hiyam A. Altaii ${ }^{2}$ and Musab M. Khalaf ${ }^{1}$ \\ ${ }^{1}$ Department of Pharmacology and Toxicology, College of Pharmacy, University of Mosul, Mosul, Iraq. \\ ${ }^{2}$ College of Sciences, University of Mosul, Mosul, Iraq. \\ *Corresponding author: hanialmukhtar@uomosul.edu.iq
}
ABSTRACT
Received
Accepted
25.11.2020
25.12.2020

Background: Statins are group of medicines that block mevalonate pathway by competitive inhibition of the rate limiting enzyme hydroxy-methylglutaryl-CoA reductase (HMG-CoA). Statins additionally inhibit the biosynthesis of important isoprenoid intermediates which have a role in peptidoglycan synthesis and cell growth. Several in-vivo and in-vitro studies have shown that certain type of statin family possess antibacterial activity in bacteraemia and sepsis.

Method: Two gram-positive pathogenic bacterial strain Staphylococcus aureus and Bacillus species were used for examining the antimicrobial activity of the lipophilic simvastatin using nutrient agar and nutrient broth and results were calculated by measuring the clear zone around the paper disk and compared with those obtained by the antibiotics, amoxycillin and ceftriaxone.

Results: Data have shown that simvastatin 1, 3, and 10 and $30 \mu \mathrm{M}$ inhibited both Staphylococcus aureus and bacillus species, it exhibited inhibitory zone of (17.9 \pm $0.6 \mathrm{~mm})$ and $(16.9 \pm 0.3 \mathrm{~mm})$, respectively.

Conclusion: the lipid soluble simvastatin, with relatively higher concentration than those obtained in-vivo, caused a significant inhibition of both Staphylococcus aureus bacteria and bacillus species.

KEYWORDS: Simvastatin, antibacterial, Staphylococcus aureus.

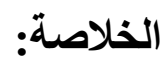

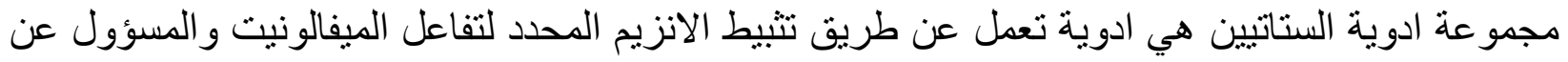

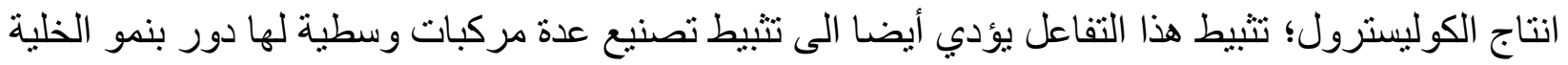

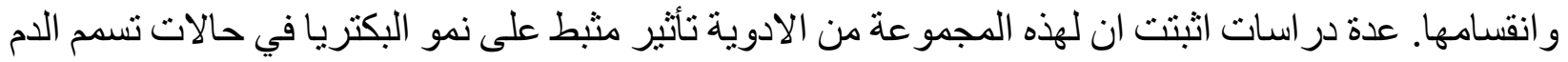

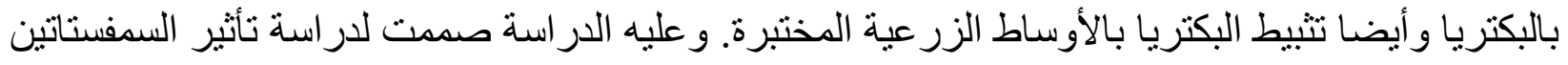
ذو الخاصية الدهنية على نمو بكتيريا المكورات العنقودية Staphylococcus aureus وبكتريا العصوية ولائه 
Bacillus species

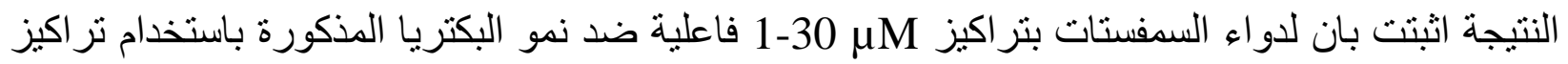
نسبيا اعلى من التر اكيز التي يصل اليها الدو اء داخل النيملت الجسم. الكلمات المفتاحية: السمفتاتين، مضاد بكتيري، بكتريا المكورات العنقودية.

\section{INTRODUCTION}

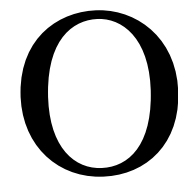

ne of the achievements in pharmacology was the discovery of statin group as a metabolite isolated from the culture of the fungus Penicillium citinum in 1970s (1), the isolated metabolite markedly reduce cholesterol in rats and dogs, since then statins family broadly utilized for the treatment of million people with hypercholesterolemia around the globe. Statins are group of medicines act by competitive inhibition of the rate limiting enzyme in hepatic cholesterol biosynthesis 3-hydroxy-3methylglutaryl-CoenzymeA reductase (HMG-CoA) (1, 2). Accordingly, they block an essential limiting stage in mevalonate pathway causing reduction in the synthesis of the malignant cholesterol i.e., LDL-cholesterol while increased catabolism of cholesterol in the body circulation (3, 4). Accordingly, statins reduce the rate of morbidity and mortality occurred as a consequence of cardiovascular complications (5-7). In general, these agents have relatively good safety profile with few adverse effects allowing their increased indications in the treatment of most patients with hyperlipidemia (8). In fact, by the inhibition of mevalonate pathway, statins additionally inhibit the biosynthesis of important isoprenoid intermediates like geranyl-geranyl diphosphate (GGPP) and farnesyldiphosphate (FPP) followed by reduction of an important signaling molecules like Rho, Ras, and Rac (9). The latter result in many extrahepatic, cholesterol-independent effects collectively known as statinspleiotropic effects improvement of endothelial function $(10,11)$, antiinflammatory effect $(12,13)$, antioxidant effect(14), antiplatelet effect (15). Moreover, multiple clinical results have shown that statins decreased the rate of mortality secondary to bacterial infection, they even have recorded role in the prophylaxis and even treatment of different bacterial infections $(16,17)$. These results suggest that statins have the ability to prevent the initiation of 
bacterial infections and inhibit bacterial growth by reduction of cholesterol biosynthesis (18). In fact, several in vivo and in vitro studies have shown that certain type of statin family possess antibacterial activity in bacteremia and sepsis (19) for example, Streptococcus, Enterococcus and Moraxella spp Staphylococcus. Aureus, S. pneumoniae Helicobacter pylori (21). Lovastatin inhibits the intracellular growth of Salmonella typhimurium (22). In addition, simvastatin combination with the first line TB treatment had shorten the duration of TB treatment in laboratory mice $(23,24)$, they even reduce the incidence of tuberculin infection in diabetic patients (25). In fact, simvastatin and atorvastatin increased the mycobactericidal effect of rifampicin in both vivo and vitro experiments (26). With limited information about the mechanism of the antibacterial effect of statin (22).

Given the fact of increased resistance of bacteria to the available antibacterial drugs because of the inappropriate prescription of the antibiotics, which is indeed considered as a serious issue in therapy $(27,28)$, therefore there is an urgent and continuous need to search for new agents against the resistant strains of bacteria (29). The use of the existing medicines primarily approved for the treatment of certain medical condition with additional antimicrobial effect has the potential to accelerate the research to discover new antimicrobial drugs since their safety have been already examined with a detailed data about their pharmacokinetics and pharmacodynamics (20). Statins were originally known as a fungal metabolite produced to inhibit bacteria by HMG-CoA reductase inhibition (1), due their significant cholesterol reducing efficacy, they commonly used for cardiovascular diseases (30), however as part of their pleiotropic effect statins also investigated for their efficacy to inhibit bacteria (31), fungi (32), parasite (33) and even virus infection (34-36). This study was designed to address in vitro effect of the lipophilic simvastatin on Staphylococcus bacteria and bacillus species, and also to determine the minimal inhibitory concentration of simvastatin on these species.

\section{MATERIALS AND METHODS}

\section{Bacterial isolates}

Two isolates of pathogenic bacteria: gram- positive cocci including Methicillin-resistant Staphylococcus aureus (MRSA) (29) the main cause of nosocomial infection i.e acquired in 
hospital, they have ability of biofilm formation which render the bacteria resistant to several types of antibiotics. The second bacteria examined was bacillus species which also resist many chemicals and antibiotics by spore formation. Gram negative bacteria like Pseudomonas aeruginosa, Klebsiella pneumonia and Escherichia coli also examined for comparison. Those bacterial isolates were obtained from Microbiology Lab/ College of Sciences at the University of Mosul. Bacterial isolates were kept in a nutrient agar according to their growth requirement for about $24 \mathrm{hr}$. at $37^{\circ} \mathrm{C}$. growth medium containing bacterial isolates were also prepared in $5 \mathrm{ml}$ nutrient broth.

\section{Chemicals}

Simvastatin tablets $20 \mathrm{mg}$ (AstraZeneca) were provided from a local pharmacy, dissolved in the suitable organic solvent DMSO, dimethyl sulfoxide, was used as a the drug solvent, which already examined in previous studies and have shown no antibacterial activity with concentration not exceeding 1\% (31, 37). Amoxycillin and ceftriaxone disc (Bio-Rad) obtained from local market.

\section{Antibacterial activity}

The activity of simvastatin as antibacterial agent was estimated by the method of disc diffusion as described before (38). The method is basically done by diffusion of agent to be tested on a solid media, a sterile petri dish was filled by the agar Mueller-Hinton (Difco ${ }^{\mathrm{TM}}$ ) (about 100 $\mathrm{mm}$ in diameter), bacteria were recovered from a frozen stock by seeding on the agar with concentration about $\left(1 \times 10^{8}\right)$, the plates were inspected for any contamination, paper disc prepared in the lab by dispersion of the paper (6 $\mathrm{mm}$ diameter) in the drug solution with stock concentrations 1,3 , and 10 and $30 \mu \mathrm{M}$. Ceftriaxone and amoxicillin disc was used as appositive control while DMSO disk was used as a negative control. The dishes were prepared and left for a bout $1 \mathrm{hr}$. at room temperature then bacterial smear was done with the drug simvastatin, then the petri dishes were incubated overnight at $37^{\circ} \mathrm{C}$ Petri. The effect antibacterial effect of simvastatin was measured as a clear zone around the paper disk which correspond to inhibition of bacterial growth and compared with those obtained by the amoxycillin and ceftriaxone (31). Then bacterial strain was smeared on the agar media in each plate. DMSO-containing plate was used as a control to exclude diluent 
effect on bacterial growth. The prepared plates were incubated for about $24 \mathrm{hr}$. at $37^{\circ} \mathrm{C}$. minimum concentration that inhibit bacterial growth was considered the minimal inhibitory concentration (MIC), where no visible bacterial growth was seen on the agar, usually the method was repeated twice for each concentration and the average calculated (figure 1).

\section{Calculation of the minimum inhibitory concentration (MIC)}

Dilutions were done serially according to standards of the National Committee for clinical laboratories (39). Tubes containing a stock solution of $1 \mathrm{mM}, 10 \mathrm{mM}$ and $30 \mathrm{mM}$ were prepared by dissolving simvastatin in 1 $\mathrm{mL}$ DMSO. From each dilution, simvastatin was added to the nutrient broth (Difco ${ }^{\mathrm{TM}}$ ) to get final concentrations of $1 \mu \mathrm{M}, 10 \mu \mathrm{M}$ and $30 \mu \mathrm{M}$. The tubes divided to three groups, control negative (C-) (blank) for standardization, control positive $\left(\mathrm{C}^{+}\right)$contain bacteria without simvastatin and the test tube contain bacteria with simvastatin with different concentration 1, 10 and $30 \mu \mathrm{M}$. Bacteria incubated with each tube except the control taking into consideration the number in comparison with MaFarland tube number 0.5 with the standard turbidity. Tubes then incubated at $37^{\circ} \mathrm{C}$ for $24 \mathrm{hr}$. the degree of turbidity then measured with Reader Eliza at wave length of $630 \mathrm{~nm}$.

\section{RESULTS}

The current data demonstrated that supratherapeutic concentration of simvastatin have a significant antimicrobial effect against Staphylococcus gram positive bacterial strain. In vitro antibacterial activity of simvastatin $30 \mu \mathrm{M}$ caused bacterial growth inhibition of Staphylococcus reflected by the inhibitory zone of $(13 \mathrm{~mm})$ on the agar media (figure 1, table 1), it also produced inhibition of bacillus bacteria with inhibition zone of (12mm), ceftriaxone (CRO) and amoxycillin $(\mathrm{Ax})$ induced a clear inhibitory zone for both strains. 
A-

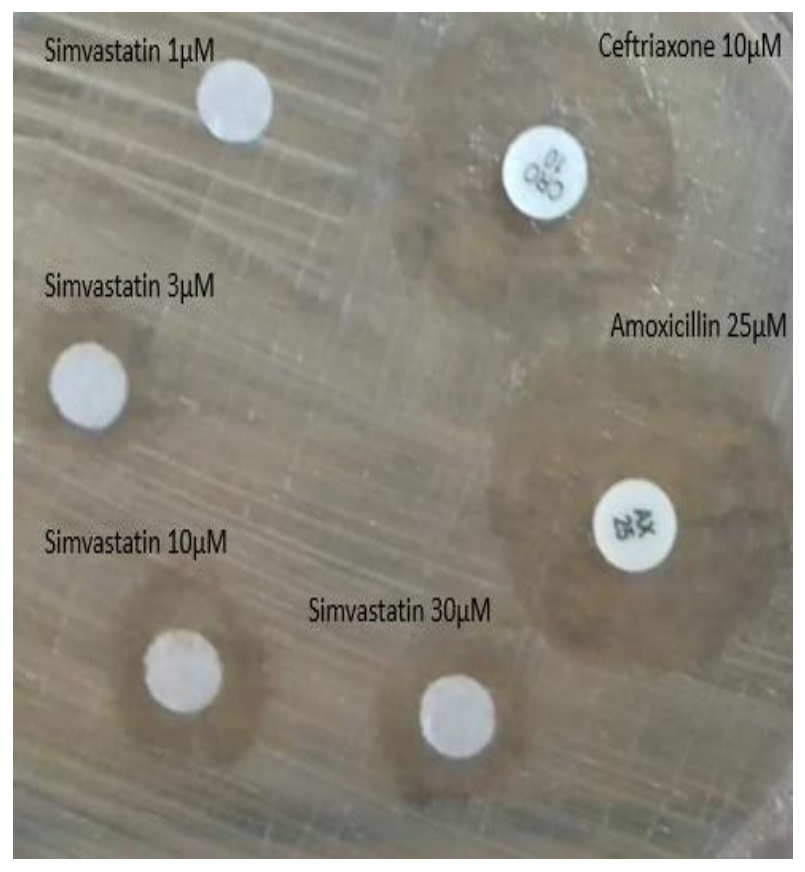

B-

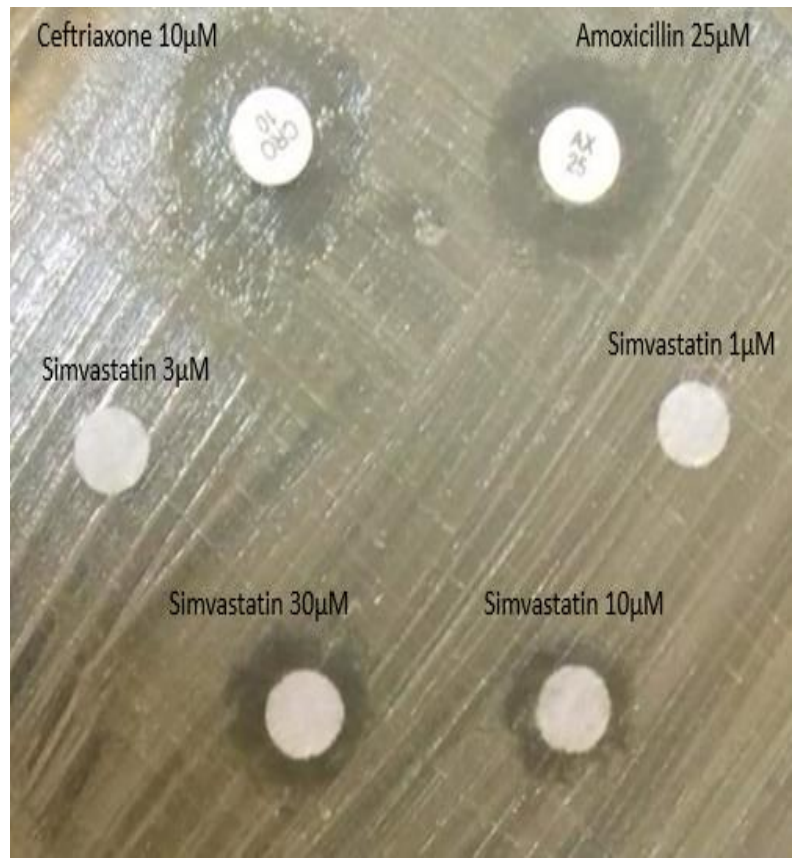

Figure 1. Antibacterial activity (measured zones of inhibition) of simvastatin $(1 \mu \mathrm{M}, 3 \mu \mathrm{M}, 10$ $\mu \mathrm{M}, 30 \mu \mathrm{M})$ on A-Staphylococcus aureus and B-bacillus species in a direct contact method, amoxycillin and ceftriaxone were used as a positive control.

However, results have shown that simvastatin with concentration up to $30 \mu \mathrm{M}$ had no effect on the gramnegative bacteria examined in our study, Pseudomonas aeruginosa, Klebsiella pneumonia and Escherichia coli, (data not shown). Results also have shown that MIC is around $10 \mu \mathrm{M}$. 
Table 1. Activity of Simvastatin (sim) $1 \mu \mathrm{M}, 10 \mu \mathrm{M}$ and $30 \mu \mathrm{M}$ against Staph. aureus and Bacillus spp. bacteria in a nutrient agar measured as inhibitory zone around each drug concentration, results compared with those obtained by the amoxycillin (Ax) and ceftriaxone (CRO).

Zone of inhibition ( $\mathrm{mm}$ )

\begin{tabular}{c|cc}
\hline Drug & Staph. aureus & Bacillus spp. \\
\hline Sim $1 \mu M$ & 10 & 10 \\
Sim $10 \mu M$ & 12 & 12 \\
Sim $30 \mu M$ & 13 & 12 \\
Ax $25 \mu M$ & 20 & 14 \\
CRO10 $\mu M$ & 18 & 16
\end{tabular}

Table 2. Activity of Simvastatin (Sim) $1 \mu \mathrm{M}, 10 \mu \mathrm{M}$ and $30 \mu \mathrm{M}$ against Staph. aureus and Bacillus spp. bacteria in nutrient broth, $\mathrm{C}$ - is control negative tube used as a blank, $\mathrm{C}+$ is a positive control without Sim. Activity measured as by turbidity with Reader Eliza at wave length $630 \mathrm{~nm}$.

\begin{tabular}{|c|c|c|}
\hline Drug & Bacillus spp. & Staph. aureus \\
\hline$C-$ & 0.015 & 0.012 \\
\hline$C+$ & 0.505 & 0.294 \\
\hline $\operatorname{Sim} 1 \mu M$ & 0.424 & 0.250 \\
\hline $\operatorname{Sim} 10 \mu M$ & 0.438 & 0.210 \\
\hline $\operatorname{Sim} 30 \mu M$ & 0.476 & 2.215 \\
\hline Stock solution & 0.246 & 0.129 \\
\hline
\end{tabular}




\section{DISCUSSION}

The use of antibiotics has long been considered as the cornerstone in the management of bacterial infections. However, the appearance of microorganism (in particular MRSA) showing resistance to many antibacterial groups even those reserved as a last choice, like meropenem (40), giving the worrying impression that the currently available antibiotics could be ineffective in the future (29). Accordingly, there is a continuous need to focus more research experiments to search for a new antibacterial in order to overcome such health challenge. The ordinary methods used to investigate novel agents are possibly unlikely to keep steps from the developed resistance by the infectious pathogens and usually such methods cost the pharmaceutical companies billions of dollars to get successfully approved antibiotic (success rate about 3.5\%). Another plan to speed up the investigation process is reusing an old agent for different use, moreover certain nonantibiotic may synergize the action of the antibiotics and thus acting as antibiotic resistance breakers (41), for example statins have a good safety profile and are well tolerated by most people, they commonly used to treat hypercholesterolemia impressively, clinical and laboratory data suggested that statins may have additive antibacterial action and thus may be used as a novel antimicrobial agent to inhibit pathogenic multidrugresistant bacteria (43). Results of the current study suggest antibacterial effect of the lipophilic simvastatin against methicillin-resistant $S$. aureus (Gram-positive bacterial species). The concentrations of simvastatin examined in the study are higher than the therapeutic concentration measured in blood of patient on simvastatin treatment around from about $10 \mathrm{nM}$ to $1 \mu \mathrm{M}$ in those treated with a daily dose of $20-60 \mathrm{mg}$ (44). Thus, simvastatin with this concentration do not have antibacterial effect in normal daily dosing. However, multiple dosing of simvastatin may result in drug accumulation in vivo at certain tissues with resultant inhibition of bacterial growth (45, 46), Current study supports previous data published by Jerwood et al, (47) which states that simvastatin has antimicrobial effect, similarly rosuvastatin and atorvastatin have antibacterial activity against both gram positive and gram negative bacteria. Another study by Masadeh et al (2012) revealed that simvastatin and atorvastatin both have antibacterial 
activity against staphylococcus aureus, Methicillin-sensitive and methicillin-resistant strains, MSSA and MRSA respectively (43). Moreover, Peter et al, (2011) showed that in-vitro incubation with lipophilic Simvastatin was effective against $S$ pneumoniae at concentration about 36 $\mu \mathrm{mol} / \mathrm{L}$, which is indeed similar to the concentration examined in our study (31). By contrast pravastatin with concentration up to $100 \mu \mathrm{g} / \mathrm{mL}$ showed no antibacterial action. On the other hand, statins inhibit the intracellular growth of Mycobacterium leprae with concentrations approximate to those physiological concentrations suggesting indirect effect of statin secondary to cholesterol depletion (48).

Statin, especially the lipophilic group, have been shown in vitro studies to have cytotoxic effect on many cell types like endothelial cells $(49,50)$, vascular smooth muscle (51-53), skeletal muscle (54), cardiac muscle (55) pancreatic cells (56) and hepatic cells (57). Previous studies suggested that by lowering cholesterol levels in the host cells statin may inhibit production of membrane protective layer produced from mevalonate pathway with resultant induction of bacterial cytotoxic effect $(58,59)$. However, this inconsistent with the results obtained from Haeri et al study which stated that lovastatin with the potent inhibitory effect on mevalonate pathway, did not have bactericidal effect on gram-positive bacteria. thus, this mechanism cannot explain statin cytotoxicity (18). Research suggested that the gram-negative bacteria synthesize isoprenoid by mevalonateindependent pathway, in addition the outer layer of the gram-negative bacteria works as barrier against statin penetration, however, data also reported that water soluble rosuvastatin, which has less ability to penetrate cell membrane, inhibited $E$. coli (18).

Previous results showed additive effect of statin especially of the lipophilic nature like simvastatin with betalactam antibiotics against certain types of bacteria like $K$. pneumoniae, by contrast, pravastatin had no additive effect with penicillin however, the mechanism of the additive effect is still not clearly defined (31). Statin group induce hypolipidemic effect via inhibition of the reductase enzyme as mentioned before, the role of HMGCoA reductase activity in bacterial cells is essential for isoprenoids and peptidoglycan synthesis and cell growth $(59,60)$ (figure 2), however, the reductase enzyme in bacteria is of 
different structure with about 1000

times less affinity towards statins (58).

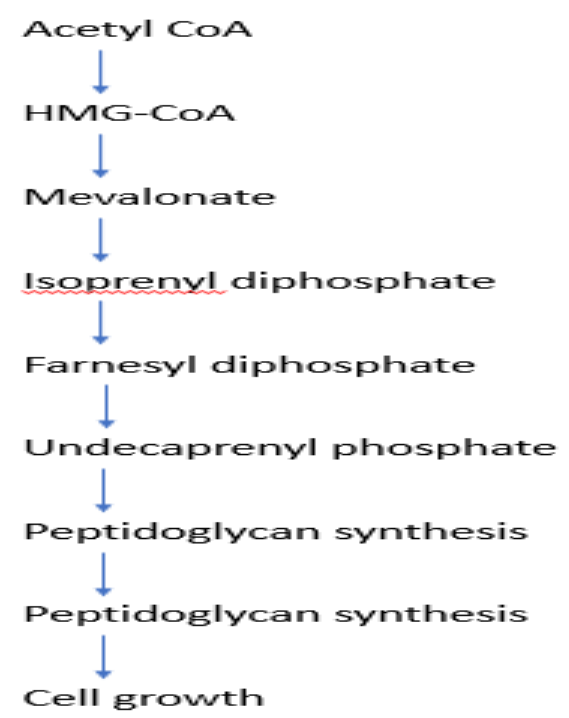

Figure 2. Representative scheme demonstrates that mevalonate contribution for the synthesis of peptidoglycan and its role in cell wall synthesis and bacterial growth.

Thus, the possibility of simvastatin to act as antibacterial agent via inhibition of mevalonate pathway is less likely, accordingly simvastatin acts in $S$. aureus by different mechanism to the mechanism known in human beings since they lack class I HMG-CoA reductase enzyme (61). On the other hand, results suggested that simvastatin had no effect on membrane integrity and thus exclude the direct cytotoxic effect of simvastatin (31). Experiments also demonstrated that simvastatin inhibited protein synthesis in bacterial species (62), other antibiotics that interferes with protein synthesis like linezolid, tetracyclines and chloramphenicol was found to inhibit to inhibit protein synthesis both in human and bacterial cells (63), the latter is due to mitochondrial inhibition in mammalian cells owing to the similarity between human and bacterial cells (64), by contrast, simvastatin have shown to be a selective inhibitor of bacterial protein synthesis, Additionally, simvastatin interferes with other biosynthetic pathways involved in energy production like glycolysis and deoxyribonucleic acid (DNA) and ribonucleic acid (RNA) synthesis (62), thus the lipophilic statin like 
simvastatin, could suppress bacterial growth by acting on multiple targets with a complex mechanism of action. To sum up, our data agree with previous experiments that have shown the antibacterial effect of the lipid soluble simvastatin with special regards to the gram-positive bacteria11. More studies are advised to investigate the mechanism (s) by which simvastatin is acting as antimicrobial agent.

\section{CONCLUSION}

Simvastatin had in-vitro antibacterial action against staphylococcus aureus

\section{REFERENCE}

1. Endo A. A historical perspective on the discovery of statins. Proc Jpn Acad Ser B Phys Biol Sci. 2010;86(5):484-93. Epub 2010/05/15.

2. Lane KT, Beese LS. Thematic review series: lipid posttranslational modifications. Structural biology of protein farnesyltransferase and geranylgeranyltransferase type I. J Lipid Res. 2006;47(4):681-99. Epub 2006/02/16.

3. Stancu C, Sima A. Statins: mechanism of action and effects. J Cell Mol Med. 2001;5(4):378-87. Epub 2002/06/18. and bacillus species with concentration above those measured in vivo.

\section{CONFLICT OF INTEREST:}

All authors declare that there is no conflict of interests.

\section{ACKNOWLEDGEMENTS:}

The authors are very grateful to the University of Mosul/ College of Pharmacy and College of Science for their provided facilities, which help to improve the quality of this work.

4. Goldstein JL, Brown MS. Regulation of the mevalonate pathway. Nature. 1990;343(6257):425-30. Epub 1990/02/01.

5. Sadowitz B, Maier KG, Gahtan V. Basic science review: Statin therapy--Part I: The pleiotropic effects of statins in cardiovascular disease. Vasc Endovascular Surg. 2010;44(4):241-51. Epub 2010/04/21. 6. Sadowitz B, Seymour K, Costanza MJ, Gahtan V. Statin therapy--Part II: Clinical considerations for cardiovascular disease. Vasc Endovascular Surg. 2010;44(6):421-33. Epub 2010/06/16. 
7. Lefer AM, Scalia R, Lefer DJ. Vascular effects of HMG CoAreductase inhibitors (statins) unrelated to cholesterol lowering: new concepts for cardiovascular disease. Cardiovasc Res. 2001;49(2):281-7. Epub 2001/02/13.

8. Bonetti PO, Lerman LO, Napoli C, Lerman A. Statin effects beyond lipid lowering--are they clinically relevant? Eur Heart J. 2003;24(3):22548. Epub 2003/02/20.

9. Buhaescu I, Izzedine $\mathrm{H}$. Mevalonate pathway: a review of clinical and therapeutical implications. Clin Biochem. 2007;40(9-10):575-84. Epub 2007/05/01.

10. Karpov RS, Koshel'skaia OA, Suslova TE, Gruzdeva OV, Zhuravleva OA. [Effect of 6-month therapy with simvastatin on lipid transport function of the blood and the state of endothelium in patients with diabetes and hypertension]. Kardiologiia. 2006;46(1):27-31. Epub 2006/02/14.

11. Skrha J, Stulc T, Hilgertova J, Weiserova H, Kvasnicka J, Ceska R. Effect of simvastatin and fenofibrate on endothelium in Type 2 diabetes. Eur J Pharmacol. 2004;493(1-3):183-9. Epub 2004/06/11.

12. Koh KK. Effects of statins on vascular wall: vasomotor function, inflammation, and plaque stability.
Cardiovasc Res. 2000;47(4):648-57. Epub 2000/09/07.

13. Sparrow $\mathrm{CP}$, Burton CA, Hernandez M, Mundt S, Hassing H, Patel S, et al. Simvastatin has antiinflammatory and antiatherosclerotic activities independent of plasma cholesterol lowering. Arterioscler Thromb Vasc Biol. 2001;21(1):11521. Epub 2001/01/09.

14. Kumar S, Srivastava N, Gomes J. The effect of lovastatin on oxidative stress and antioxidant enzymes in hydrogen peroxide intoxicated rat. Food Chem Toxicol. 2011;49(4):898902. Epub 2010/12/28.

15. Massy ZA, Keane WF, Kasiske BL. Inhibition of the mevalonate pathway: benefits beyond cholesterol reduction?

Lancet. 1996;347(8994):102-3. Epub 1996/01/13.

16. Merx MW, Liehn EA, Janssens U, Lutticken R, Schrader J, Hanrath P, et al. HMG-CoA reductase inhibitor simvastatin profoundly improves survival in a murine model of sepsis. Circulation. 2004;109(21):2560-5. Epub 2004/05/05.

17. Souza Neto JL, Araujo Filho I, Rego AC, Dominici VA, Azevedo IM, Egito ES, et al. Effects of simvastatin in abdominal sepsis in rats. Acta Cir Bras. 2006;21 Suppl 4:8-12. Epub 2007/02/13. 
18. Haeri MR, White K, Qharebeglou M, Ansar MM. Cholesterol suppresses antimicrobial effect of statins. Iran J Basic Med Sci. 2015;18(12):1253-6.

Epub

2016/02/16.

19. Merx MW, Liehn EA, Graf J, van de Sandt A, Schaltenbrand M, Schrader J, et al. Statin treatment after onset of sepsis in a murine model improves survival. Circulation. 2005;112(1):117-24. Epub 2005/07/07.

20. Hennessy E, Adams C, Reen FJ, O'Gara F. Is There Potential for Repurposing Statins as Novel Antimicrobials? Antimicrob Agents Chemother. 2016;60(9):5111-21 . Epub 2016/06/22.

21. Liao WC, Huang MZ, Wang ML, Lin CJ, Lu TL, Lo HR, et al. Statin Decreases Helicobacter pylori Burden in Macrophages by Promoting Autophagy. Front Cell Infect Microbiol. 2016;6:203. Epub 2017/02/02.

22. Catron DM, Lange Y, Borensztajn J, Sylvester MD, Jones BD, Haldar K. Salmonella enterica serovar Typhimurium requires nonsterol precursors of the cholesterol biosynthetic pathway for intracellular proliferation. Infect Immun. 2004;72(2):1036-42. Epub 2004/01/27.
23. Guerra-De-Blas PDC, TorresGonzalez P, Bobadilla-Del-Valle M, Sada-Ovalle I, Ponce-De-LeonGarduno A, Sifuentes-Osornio J. Potential Effect of Statins on Mycobacterium tuberculosis Infection. J Immunol Res. 2018;2018:7617023. Epub 2018/12/26.

24. Dutta NK, Bruiners N, Pinn ML, Zimmerman MD, Prideaux B, Dartois $\mathrm{V}$, et al. Statin adjunctive therapy shortens the duration of TB treatment in mice. $\mathrm{J}$ Antimicrob Chemother. 2016;71(6):1570-7. Epub 2016/02/24. 25. Lee MY, Lin KD, Hsu WH, Chang HL, Yang YH, Hsiao PJ, et al. Statin, calcium channel blocker and Beta blocker therapy may decrease the incidence of tuberculosis infection in elderly Taiwanese patients with type 2 diabetes. Int J Mol Sci. 2015;16(5):11369-84. Epub 2015/05/21.

26. Lobato LS, Rosa PS, Ferreira Jda S, Neumann Ada S, da Silva MG, do Nascimento DC, et al. Statins increase rifampin mycobactericidal effect. Antimicrob Agents Chemother. 2014;58(10):5766-74.

Epub 2014/07/23.

27. Aslam B, Wang W, Arshad MI, Khurshid M, Muzammil S, Rasool $\mathrm{MH}$, et al. Antibiotic resistance: a rundown of a global crisis. Infect Drug 
Resist. 2018;11:1645-58. Epub 2018/10/24.

28. Rather IA, Kim BC, Bajpai VK, Park YH. Self-medication and antibiotic resistance: Crisis, current challenges, and prevention. Saudi J Biol Sci. 2017;24(4):808-12. Epub 2017/05/12.

29. WHO. WHO publishes list of bacteria for which new antibiotics are urgently needed. 2017.

30. Wang CY, Liu PY, Liao JK. Pleiotropic effects of statin therapy: molecular mechanisms and clinical results. Trends Mol Med. 2008;14(1):37-44. Epub 2007/12/11.

31. Bergman P, Linde C, Putsep K, Pohanka A, Normark S, HenriquesNormark B, et al. Studies on the antibacterial effects of statins--in vitro and in vivo. PLoS One. 2011;6(8):e24394. Epub 2011/09/14.

32. Qiao J, Kontoyiannis DP, Wan Z, Li R, Liu W. Antifungal activity of statins against Aspergillus species. Med Mycol. 2007;45(7):589-93. Epub 2007/11/23.

33. Rojo-Arreola L, Long $\mathrm{T}$, Asarnow D, Suzuki BM, Singh R, Caffrey CR. Chemical and genetic validation of the statin drug target to treat the helminth disease, schistosomiasis. PLoS One. 2014;9(1):e87594. Epub 2014/02/04.
34. Castiglione V, Chiriaco M, Emdin M, Taddei S, Vergaro G. Statin therapy in COVID-19 infection. Eur Heart J Cardiovasc Pharmacother. 2020;6(4):258-9. Epub 2020/04/30.

35. Hariyanto TI, Kurniawan A. Statin therapy did not improve the inhospital outcome of coronavirus disease 2019 (COVID-19) infection. Diabetes Metab Syndr. 2020;14(6):1613-5. Epub 2020/09/04. 36. Shrivastava-Ranjan P, Flint $M$, Bergeron E, McElroy AK, Chatterjee P, Albarino CG, et al. Statins Suppress Ebola Virus Infectivity by Interfering with Glycoprotein Processing. mBio. 2018;9(3). Epub 2018/05/03.

37. Pottz GE, Rampey JH, Benjamin F. The effect of dimethyl sulfoxide (DMSO) on antibiotic sensitivity of a group of medically important microorganisms: preliminary report. Ann N Y Acad Sci. 1967;141(1):261-72. Epub 1967/03/15.

38. Luangtongkum $\mathrm{T}$, Morishita TY, El-Tayeb AB, Ison AJ, Zhang Q. Comparison of antimicrobial susceptibility testing of Campylobacter spp. by the agar dilution and the agar disk diffusion methods. J Clin Microbiol. 2007;45(2):590-4. Epub 2006/11/24.

39. Igawa G, Casey M, Sawabe E, Nukui Y, Okugawa S, Moriya K, et al. 
Comparison of agar dilution and broth microdilution methods for Clostridium difficile antimicrobial susceptibility testing. J Glob Antimicrob Resist. 2016;7:43-5. Epub 2016/09/07.

40. Kayser FH, Morenzoni G, Strassle A, Hadorn K. Activity of meropenem, against gram-positive bacteria. J Antimicrob Chemother. 1989;24 Suppl A:101-12. Epub 1989/09/01.

41. Ko HHT, Lareu RR, Dix BR, Hughes JD. Statins: antimicrobial resistance breakers or makers? PeerJ. 2017;5:e3952. Epub 2017/11/01.

42. Zhou Q, Liao JK. Statins and cardiovascular diseases: from cholesterol lowering to pleiotropy. Curr Pharm Des. 2009;15(5):467-78. Epub 2009/02/10.

43. Masadeh $\mathrm{M}$, Mhaidat $\mathrm{N}$, Alzoubi K, Al-Azzam S, Alnasser Z. Antibacterial activity of statins: a comparative study of atorvastatin, simvastatin, and rosuvastatin. Ann Clin Microbiol Antimicrob. 2012;11:13. Epub 2012/05/09.

44. Laufs U, La Fata V, Plutzky J, Liao JK. Upregulation of endothelial nitric oxide synthase by HMG CoA reductase inhibitors. Circulation. 1998;97(12):1129-35. Epub 1998/04/16.

45. Ho CK, Walker SW. Statins and their interactions with other lipid- modifying medications: safety issues in the elderly. Ther Adv Drug Saf. 2012;3(1):35-46. Epub 2012/02/01.

46. Bjorkhem-Bergman L, Lindh $\mathrm{JD}$, Bergman P. What is a relevant statin concentration in cell experiments claiming pleiotropic effects? $\mathrm{Br} \mathrm{J}$ Clin Pharmacol. 2011;72(1):164-5. Epub 2011/01/13. 47. Jerwood S, Cohen J. Unexpected antimicrobial effect of statins. J Antimicrob Chemother. 2008;61(2):362-4. Epub 2007/12/19. 48. Mattos KA, Oliveira VC, Berredo-Pinho M, Amaral JJ, Antunes LC, Melo RC, et al. Mycobacterium leprae intracellular survival relies on cholesterol accumulation in infected macrophages: a potential target for new drugs for leprosy treatment. Cell Microbiol. 2014;16(6):797-815. Epub 2014/02/21.

49. Newton CJ, Ran G, Xie YX, Bilko D, Burgoyne CH, Adams I, et al. Statin-induced apoptosis of vascular endothelial cells is blocked by dexamethasone. $\mathrm{J}$ Endocrinol. 2002;174(1):7-16. Epub 2002/07/06.

50. Li X, Liu L, Tupper JC, Bannerman DD, Winn RK, Sebti SM, et al. Inhibition of protein geranylgeranylation and RhoA/RhoA kinase pathway induces apoptosis in human endothelial cells. J Biol Chem. 
2002;277(18):15309-16. Epub 2002/02/13.

51. Blanco-Colio LM, Villa A, Ortego M, Hernandez-Presa MA, Pascual A, Plaza JJ, et al. 3-Hydroxy3-methyl-glutaryl coenzyme A reductase inhibitors, atorvastatin and simvastatin, induce apoptosis of vascular smooth muscle cells by downregulation of $\mathrm{Bcl}-2$ expression and Rho A prenylation. Atherosclerosis. 2002;161(1):17-26. Epub 2002/03/08.

52. Boucher K, Siegel CS, Sharma P, Hauschka PV, Solomon KR. HMG$\mathrm{CoA}$ reductase inhibitors induce apoptosis in pericytes. Microvasc Res. 2006;71(2):91-102. Epub 2006/01/24. 53. Guijarro C, Blanco-Colio LM, Ortego M, Alonso C, Ortiz A, Plaza JJ, et al. 3-Hydroxy-3-methylglutaryl coenzyme a reductase and isoprenylation inhibitors induce apoptosis of vascular smooth muscle cells in culture. Circ Res. 1998;83(5):490-500. Epub 1998/09/12.

54. Dirks AJ, Jones KM. Statininduced apoptosis and skeletal myopathy. Am J Physiol Cell Physiol. 2006;291(6):C1208-12. Epub 2006/08/04.

55. Demyanets S, Kaun C, Pfaffenberger S, Hohensinner PJ, Rega G, Pammer J, et al.
Hydroxymethylglutaryl-coenzyme A reductase inhibitors induce apoptosis in human cardiac myocytes in vitro. Biochem Pharmacol. 2006;71(9):1324-30.

Epub 2006/03/17.

56. Urbano $\mathrm{F}$, Bugliani $\mathrm{M}$, Filippello A, Scamporrino A, Di Mauro S, Di Pino A, et al. Atorvastatin but Not Pravastatin Impairs Mitochondrial Function in Human Pancreatic Islets and Rat beta-Cells. Direct Effect of Oxidative Stress. Sci Rep. 2017;7(1):11863. Epub 2017/09/21.

57. Kubota T, Fujisaki K, Itoh Y, Yano T, Sendo T, Oishi R. Apoptotic injury in cultured human hepatocytes induced by HMG-CoA reductase inhibitors. Biochem Pharmacol. 2004;67(12):2175-86. Epub 2004/05/28.

58. Heuston S, Begley M, Gahan CGM, Hill C. Isoprenoid biosynthesis in bacterial pathogens. Microbiology (Reading). 2012;158(Pt 6):1389-401. Epub 2012/04/03.

59. Wilding EI, Brown JR, Bryant AP, Chalker AF, Holmes DJ, Ingraham KA, et al. Identification, evolution, and essentiality of the mevalonate pathway for isopentenyl diphosphate biosynthesis in grampositive cocci. J Bacteriol. 
2000;182(15):4319-27.

2000/07/14.

60. Matsumoto Y, Yasukawa J, Ishii M, Hayashi Y, Miyazaki S, Sekimizu K. A critical role of mevalonate for peptidoglycan synthesis in Staphylococcus aureus. Sci Rep. 2016;6:22894. Epub 2016/03/11.

61. Hedl M, Rodwell VW. Inhibition of the class II HMG-CoA reductase of Pseudomonas mevalonii. Protein Sci. 2004;13(6):1693-7. Epub 2004/05/21.

62. Thangamani S, Mohammad H, Abushahba MF, Hamed MI, Sobreira TJ, Hedrick VE, et al. Exploring simvastatin, an antihyperlipidemic drug, as a potential topical antibacterial agent. Sci Rep. 2015;5:16407. Epub 2015/11/11.

63. McKee EE, Ferguson M, Bentley AT, Marks TA. Inhibition of mammalian mitochondrial protein synthesis by oxazolidinones. Antimicrob Agents Chemother. 2006;50(6):2042-9. Epub 2006/05/26. 64. Riesbeck K, Bredberg A, Forsgren A. Ciprofloxacin does not inhibit mitochondrial functions but other antibiotics do. Antimicrob Agents Chemother. 1990;34(1):167-9. Epub 1990/01/01. 